\title{
FIRST RECORD OF THE LESSER AMBERJACK, SERIOLA FASCIATA (ACTINOPTERYGII: PERCIFORMES: CARANGIDAE), IN THE LEVANT
}

\author{
Oren SONIN ${ }^{1}$, Pierre SALAMEH ${ }^{1}$, and Daniel GOLANI ${ }^{2 *}$ \\ ${ }^{1}$ Department of Fisheries, Ministry of Agriculture, P.O. Box 1213, Kiryat Haim, 26105, Israel \\ ${ }^{2}$ Department of Evolution, Systematics and Ecology, The Hebrew University of Jerusalem, 91904 Jerusalem, Israel
}

Sonin O., Salameh P., Golani D. 2009. First record of the lesser amberjack, Seriola fasciata

(Actinopterygii: Perciformes: Carangidae), in the Levant. Acta Ichthyol. Piscat. 39 (1): 71-73.

Abstract. The lesser amberjack, Seriola fasciata, was recorded for the first time in the Levant. This species was known hitherto from the Atlantic Ocean and western and central Mediterranean and southeastern Aegean Sea.

Keywords: Seriola fasciata, eastern Mediterranean, first record

The vast majority of Mediterranean ichthyofauna is of Atlantic origin. Since the opening during the Pliocene era some 5.32 million years ago at the Straits of Gibraltar allowed a passageway, connecting the Atlantic Ocean to the Mediterranean, there has been an ongoing process of influx of organisms eastward into the Mediterranean Sea.

Golani et al. (2002) noted that most of the Atlantic fish recorded lately from the Mediterranean are vagrant or episodic sojourners that fail to establish sustainable populations in their new region. An exception to this rule is the lesser amberjack, Seriola fasciata (Bloch, 1793), that was first recorded in the Mediterranean in 1989 as reported by Massutí and Stefanescu (1993); a decade later, this species was considered to be a commercial species in the central Mediterranean (Andaloro et al. 2005) and short time later it was recorded in the vicinity of Rhodes at the south-eastern Aegean Sea (Corsini et al. 2006) which was thought to be its furthest point eastward in its Mediterranean distribution.

On 12 September 2008 two young specimens of Seriola fasciata (Bloch, 1793) were captured by the trawler F/V NITZAN at Haifa, Israel, at the easternmost side of the Mediterranean. One of the specimens, $151 \mathrm{~mm}$ SL, (Fig. 1) was deposited in the Hebrew University Fish Collection (HUJ) and received the catalogue number HUJ 19774.

This finding constitutes the first record of S. fasciata in the Levant (Fig. 2).

\section{Description of the Eastern Mediterranean specimen of Seriola fasciata:}

Body oblong, moderately deep and slightly compressed. Head (32.4\%) with slightly convex profile, depth $(39.8 \%)$ at the origin of second dorsal fin, predorsal
$(38.9 \%)$, preanal $(67.0 \%)$, all percentage of SL. Eye $(24.3 \%)$, interorbital $(32.9 \%)$, caudal peduncle $(18.2 \%)$, all percentage of head length. Two dorsal fins, the first small with eight spines, the last spine being minute and embedded. Second dorsal fin with one spine and 31 rays, the first $1-5$ rays the longest, gradually decreasing in length until penultimate the last ray elongated. Anal fin with two small spines separated from the rest of the fin. The soft ray portion with 18 rays, originating beneath the 17 th dorsal ray. Small pectoral fin with 20 rays. Ventral fin with one spine and five rays. Developed gill rakers, five on the upper gill arch and 17 on the lower including the raker in the angle of the arch. Very small scales, 112 in the lateral line. Terminal mouth, upper jaw with a narrow supramaxilla (20\% of its posterior depth), hardly reaching the vertical of eye centre. Minute teeth arranged in a band.

Colour: Body background is grey with eight dark bars. The first bar is darkest, extending from eye to nape. The rest are irregular and broken, the 4th to 8th extending into the dorsal fin. Dark spot at midpoint of caudal fin. First dorsal fin dark. Second dorsal, anal and caudal fins with touch of yellow.

Counts, measurements, colour pattern and especially the narrow supramaxilla agree with the description of S. fasciata and distinguish it from all Atlantic and Mediterranean specimens of the genus Seriola (cf. SmithVaniz and Berry 1981, Smith-Vaniz 2002).

Remarks. Seriola fasciata has an Atlantic distribution: Madeira and the Canary Islands - in the eastern coast - and from Massachusetts to the Gulf of Mexicoon the western coast. Adult specimens found mainly near the substrate while young fish are also pelagic. It feeds

\footnotetext{
* Correspondence: Dr. Daniel Golani, Department of Evolution, Systematics and Ecology, The Hebrew University of Jerusalem, 91904 Jerusalem, Israel, phone: +972-2-6585872, fax: +973-2-6584741 e-mail: dgolani@cc.huji.ac.il
} 


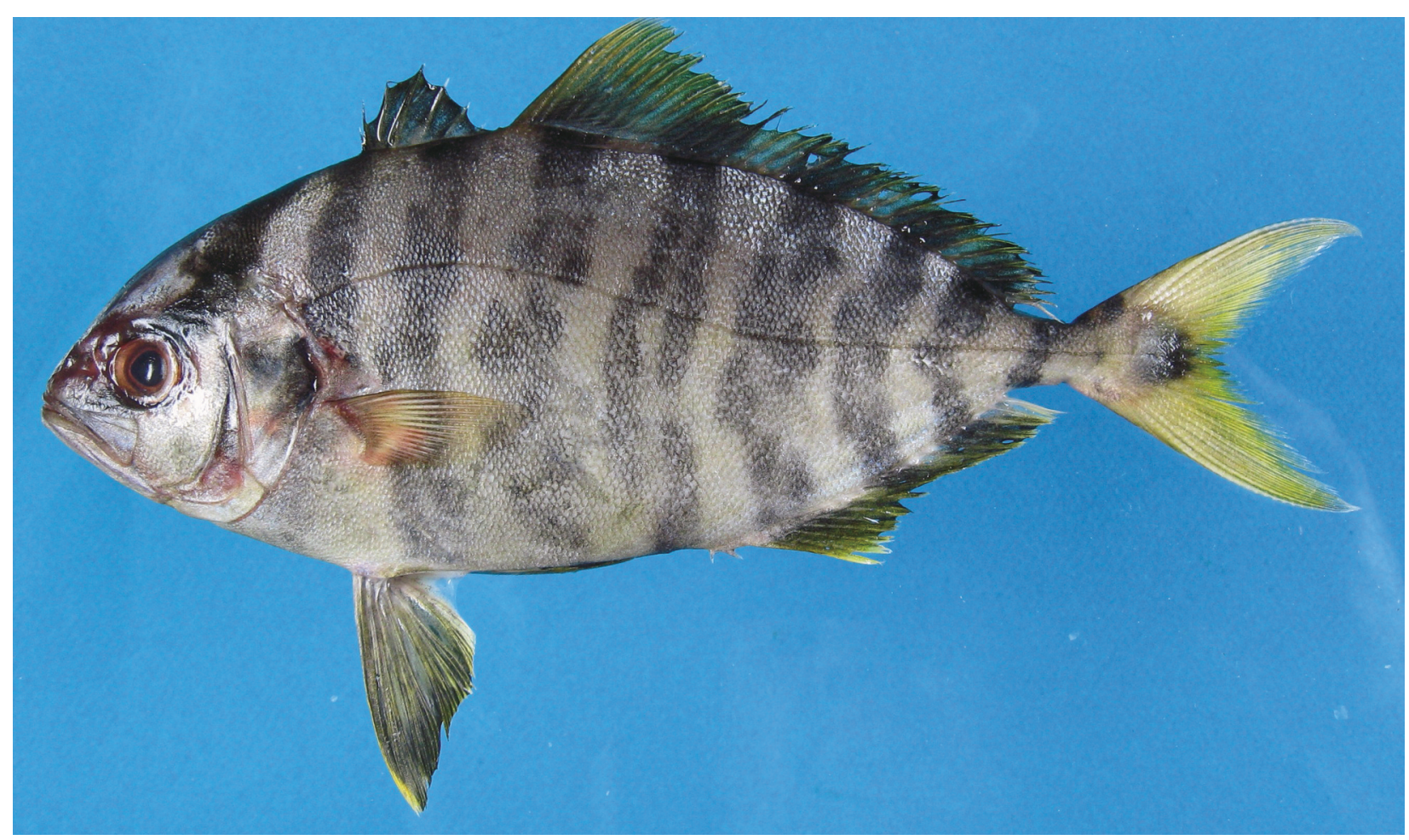

Fig. 1. Seriola fasciata $151 \mathrm{~mm}$ SL from Haifa Bay, Israel, Eastern Mediterranean (HUJ 19774)

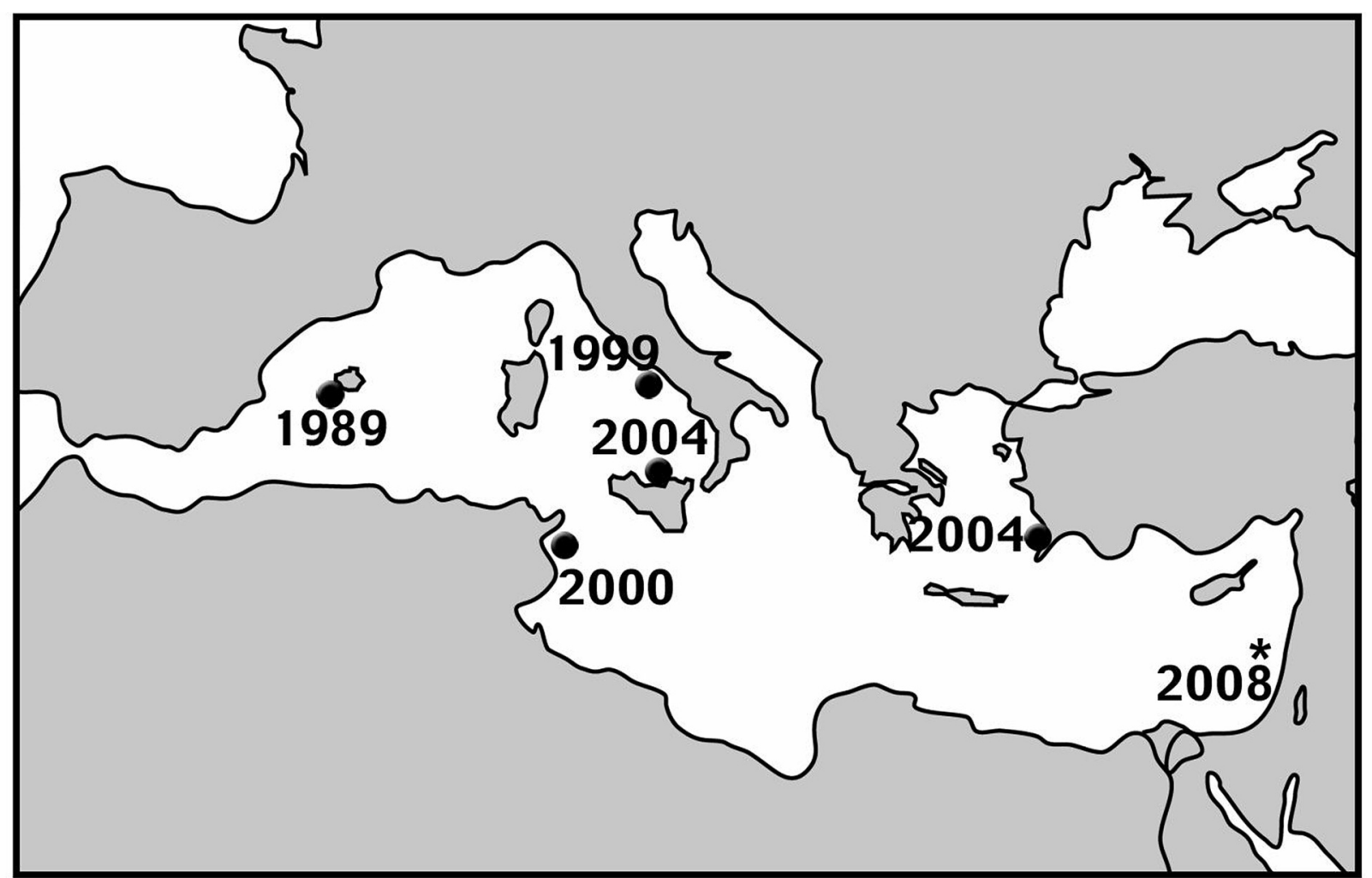

Fig. 2. Previous records of Seriola fasciata in the Mediterranean (•) (see: Andaloro et al. 2005, Corsini et al. 2006) and the present record $(*)$ 
chiefly on cephalopods and fishes and can reach $675 \mathrm{~mm}$ (fork length) and $4.6 \mathrm{~kg}$ (total weight).

Seriola fasciata was first recorded from the Mediterranean by Massutí and Stefanescu (1993) from the Balearic Islands. In the following years two other members of this genus were recorded in the Mediterranean; Pizzicori et al. (2000) reported a large school of $S$. carpenteri Mather, 1971 from Lampedusa Island and later Castriota et al. (2004) reported two specimens of $S$. rivoliana Valenciennes, 1833 from the same area. All these three newly recorded species from the Mediterranean joined the indigenous species $S$. dumerili (Risso, 1810).

The finding of two specimens of Seriola fasciata in the Haifa Bay constitutes a great extension of its Mediterranean distribution. It will be interesting to monitor its development in the Eastern Mediterranean and to see if it will succeed in building a sustainable population in the region.

\section{ACKNOWLEDGMENTS}

We would like to thank Mr. Michael Zamel and the crew of the F/V NITZAN for providing the specimen.

\section{REFERENCES}

Andaloro F., Falautano M., Sinopoli M., Passarelli F.M., Pipitone, C., Addis P., Cau, A., Castriota L. 2005. The lesser amberjack Seriola fasciata (Perciformes: Carangidae) in the Mediterranean: a recent colonist? Cybium 29: 141-145.

Castriota L., Falautano M., Greco S., Andaloro F. 2004. Second record of Seriola rivoliana (Carangidae) in the Mediterranean. Cybium 28: 265-266.
Corsini M., Margies P., Kondilatos G., Economidis P.E. 2006. Three new exotic fish records from the SE Aegean Greek waters. Scientia Marina 70: 319-323.

Golani D., Orsi-Relini L., Massuti E., Quignard J.P. 2002. CIESM atlas of exotic species in the Mediterranean. Vol. 1. Fishes. Briand F. (ed.) CIESM Publications, Monaco.

Massutí E., Stefanescu C. 1993. First record of Seriola fasciata (Bloch, 1793) (Osteichthyes: Carangidae) in the Mediterranean. Journal of Fish Biology 42: 143-144. DOI: 10.1111/j.1095-8649.2002.tb00296.x.

Pizzicori P., Castriota L., Marino D., Andaloro F. 2000. Seriola carpenteri: a new immigrant in the Mediterranean from the Atlantic Ocean. Journal of Fish Biology 57: 1335-1338. DOI: 10.1111/j.1095-8649.2000.tb00491.x.

Smith-Vaniz W.F. 2002. Carangidae. Pp. 1426-1460. In: Carpenter K. (ed.) The living marine resources of the Western Central Atlantic. Vol. 3: Bony fishes, part 2 (Opistognathidae to Molidae, Sea turtles and marine mammals. FAO Species Identification Guide for Fishery Purposes and American Society of Ichthyologists and Herpetologists. Special Publication No. 5, FAO, Rome.

Smith-Vaniz W.F., Berry F.H. 1981. Carangidae. pag. var. In: Fischer W., Bianchi G., Scott W.B. (eds.) FAO species identification sheets for fishery purposes. Eastern Central Atlantic; fishing area 34, 47 (in part). Canada Funds-inTrust. Ottawa, Department of Fisheries and Oceans Canada and FAO of the United Nations. Vol. 1.

Received: 24 November 2008

Accepted: 21 January 2009

Published electronically: 20 May 2009 